\title{
LXI. Notice of a tertiary deposit lately discovered in the neighbourhood of Belfast
}

\author{
James Bryce Jun. M.A. F.G.S.
}

To cite this article: James Bryce Jun. M.A. F.G.S. (1845) LXI. Notice of a tertiary deposit lately discovered in the neighbourhood of Belfast , Philosophical Magazine Series 3, 26:174, 433-436, DOI: $10.1080 / 14786444508645160$

To link to this article: http://dx.doi.org/10.1080/14786444508645160

曲 Published online: 30 Apr 2009.

Submit your article to this journal $\lceil\pi$

Џ Article views: 2

Q View related articles $\asymp$ 
Forbes included, in his views, the sliding of glaciers by melting, that I did so, on the same ground on which Mr. Hopkins denies that De Saussure regarded a glacier as a rigid mass; namely, that to suppose otherwise, would be to attribute an absurdity to a distinguished and philosophical traveller. With regard to Mr. Hopkins's assertion, that we may as justly include in De Saussure's theory the true part of Prof. Forbes's, as in Prof. Forbes's the true part of I) Saussure's, I suggest, that Prof. Forbes wrote sixty years later than De Saussure, and had read and carefully studied De Saussure's writings; and that this makes a great difference in the chance of one having adopted the true part of the other's theory. Prof. Forbes's theory includes what was true in that of De Saussure, in the same way that Copernicus's theory included what was true in that of Ptolemy. Mr. Hopkins has used the word "appropriation" in reference to this subject; but nothing has been said which is any excuse for the introduction of such a term. I am, dear Sir,

Your faithful and obedient Servant,

Trinity College, Cambridge, April 12, 1845.

W. WHEWELL.

LXI. Notice of a Tertiary Deposit lately discovered in the neighbourhood of Belfast. By James Bnyce, Jun., M.A., F.G.S.

I $\mathrm{N}$ the winter of 1842-4.3, a shelly deposit was discovered at Belfast in excavating the lower basin for the new waterworks. A short notice of it, drawn up by Mr. Hyndman and myself, with a list of the shells, was at Captain Portlock's request furnished to him for insertion in the appendix to his Report on the Geology of Londonderry, Tyrone and Fermanagh, then passing through the press. In the cuttings for the Cavehill railroad, made within the last few months, the deposit was again exposed through a considerable space, and in a direction somewhat transverse to the former cuttings, by which some new facts and additional species have been discovered.

The deposit is situated about one mile north of the town, at the height of 106 feet above low water in the bay, and consists in the lower part of a very tenacious compact gravelly clay, of a bluish-gray colour, from eight to twelve feet thick; and in the upper part of stratified red sand and red clay five or six feet thick; above this is a thick recent alluvium. 'The lower blue clay rests immediately on the gypseous marls of the new red sandstone, and is the chief repository of the shells, Phil. Mag. S. 3. Vol.26. No. 174. May 1845. $2 \mathrm{G}$ 


\section{Mr. Bryce on a Tertiary Deposit lately discovered}

a few only being found in the upper sand and clay. The shells are in every state of preservation: some are rolled and polished; some, though strong shells, are broken into fragments, while others, though of a fragile nature, are in a state of perfect preservation. The same observation has been made by Captain Portlock respecting the tertiary clays of Londonderry (Report, chap. vi.); and he points out the conclusion to be drawn from it respecting the origin of these beds.

There have been identified in all forty-five species of shells, and there are fragments which may belong to others. From the occurrence of Nucula oblonga, which is now extinct, and found fossil in the crag and Sicilian pliocene beds, and of Fusus contrarius, also a crag fossil, and of which no living locality is known, the deposit was assigned by us to the newer pliocene epoch, In this view we were supported by Captain Portlock, who, prior to the discovery of the Belfast deposit, had assigned the same age to certain calcareous clays and gravels in Londonderry. These contain, however, a very limited number of species in comparison to those which occur with us. They extend inland about fifteen miles, and in elevation far surpass our deposits, ranging from near the sealevel to between 400 and 500 feet; yet they were found to contain but three species, Nucula oblonga, Turritella terebra and Cyprina Islandica, all of which occur also in the Belfast beds. In an excellent paper by Mr. Oldham on the state of our knowledge of these deposits in Ireland, an abstract of which was published last year in the Proceedings of the Geological Society of Dublin (vol. iii. part 1. p. 61), only sixteen species are enumerated as the result of his own researches, and those of Dr, Scouler and others in various parts of the country. The Belfast deposit alone thus contains about three times the number of species yet described as occurring in Ireland. This is, I suppose, to be explained less by any original difference in the conditions under which this deposit took place, than by the watchfulness of various collectors during the removal of the great quantity of matter, about 10,000 cubic yards, which was taken from these beds alone.

In the lower clay, in which the shells chiefly occur, rounded fragments of almost all the primary and secondary rocks of this country are found with many fossils of the latter class. The adjoining mountains, which are composed of the upper secondary and trap rocks, afford an obvious origin for some of the pebbles; for the others a more distant origin must be sought. The Mourne range is excluded, as containing but very few of these. They may have been transported from 
North-western Donegal, a distance of seventy or eighty miles, as such rocks occur there in situ, but they bear a much closer resemblance to the pebbles of Scottish origin which strew the shores at the mouth of the bay; and thus they point back to that remote condition of things, when the whole trap district was still rising above the level of the sea, but when the elevated country at the base of the mountains, from Belfast to Carrickfergus, was yet under water, and the waves were beating against the base of the basaltic precipices.

The following is a list of the shells :-

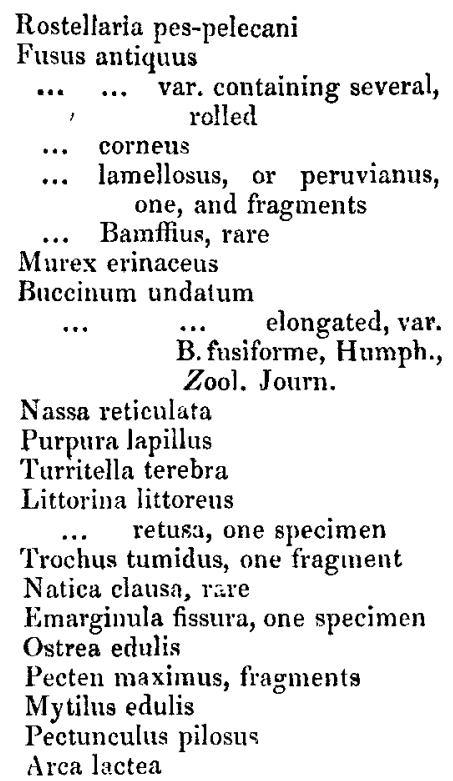

Nucula oblonga (Brown). ... margaritacea, fragments

Cardium echinatum

... edule

... nodosum

Tellina solidula

Mactra elliptica

... truncata

Cyprina Islandica

Venus ovata

... gallina

... decussata

... aurea

Astarte Damnonia

... multicostata, abundant

... Scotica

... Gairensis, abundant

... compressa (Smith), same as Clyde shell

Amphidesma compressum

Saxicava rugosa

Serpula vermicularis

Balanus, many pieces with a few valves.

A comparison of this list with the shells of the Clyde deposits, described by Mr. Smith of Jordan Hill, and with those of other parts of Ireland, suggests many interesting reflections. One most abundant species, Astarte Gairensis, abounds also in the Clyde deposits, and is found near Dublin in several places, but does not inhabit Belfast Bay at present, and is rare in the Clycle. The occurrence of this species, of the Nucula oblonga, and some others, seems to connect, as of one age, the deposits of the west of England, the Isle of Mau, the eastern and northern parts of Ireland, and the basin of the Clyde. I must, however, refer to Mr. Oldham's paper already mentioned for some very interesting remarks on this subject. See also Mr. Lyell's observations on the connexion of the Canadian, Swe- 
dish and Scottish deposits (Geological Proceedings, vol. iii. p. $\left.119^{*}\right)$.

Owing to the thick alluvial cover, the precise extent of this shelly deposit cannot be determined: it is certainly known to occupy several acres, but it may extend much farther. Traces of a clay deposit with shells have been noticed at several places on the northern shores of the bay, at heights reaching from near the sea-level to sixty feet. They have been passed through in well-borings, but have yielded only a few fragments. The intended cuttings on two projected lines of railway will give complete sections of the superficial clay beds, and it is to be hoped, will furnish some interesting facts.

LXII. Queries regarding Dr. Young's Optometer.

To the Editors of the Philosophical Magazine and Journal. Gentiemen,

HOWEVER eminent the abilities of the late Dr. Young, he certainly did not study the art of writing in such a style, that not only he might possibly be understood by those of his readers who comprehended the subject nearly as well as himself, but that he could not possibly be misunderstood by any one of ordinary capacity and attention-an invaluable art, too little attended to by English philosophers.

I should feel obliged to any of your readers, who understand Dr. Young's optometer, as described in his Natural Philosophy, vol. ii. p. 576, and the scales of that instrument as represented in fig. 72 of plate 9 , who would give, through your pages, a plain and perspicuous explanation of them.

The following queries will direct attention to some of the particulars on which I wish information:-

1. Dr. Young says, "In order to adapt the instrument to the use of presbyopic eyes, the other end must be furnished with a lens." Now, which end is suited for examining the focal distance of normal eyes, the one with or that without the lens?

2. One line of the scale is a scale of inches; another is divided according to a "table here calculated, by means of which, not only diverging, but also parallel and converging rays from the lens are referred to their virtual focus." What is the calculation here referred to? In the series of numbers, the mark of infinity occurs, while some of the numbers have the negative sign before them, and others after them; what does this signify?

* Insirted also in I hil. Mag., S. 3. vol. xv. p. 400. 